\title{
実験的正円空膜破裂治痛過程の観察
}

\author{
暁清文・柳原 弘男・有友宏・柳原 尚明
}

\section{Healing Process of the Experimentally Produced Round-Window-Membrane Perforation}

\author{
Kiyofumi Gyo, Hiroo Yanagihara, Hiroshi Aritomo \\ and Naoaki Yanagihara
}

(Ehime University)

Healing processes of the experimentally produced, round-window-membrane perforation were studied light and scanning-electronmicroscopically (SEM) in 33 guinea pigs. Some resulted in spontaneous healing as early as 3 days and all the others healed within 10 days. These results suggest that the round window membrane has a pronounced tendency to heal. In light microscopical examination, the sectioned preparations were stained by Gomori's aldehyde-fuchsin method because there was a great amount of elastic fibers in the middle layer of the round-window membrane.

Histological observations proved that the perforations of the roundwindow membrane were closed by covering with granulation, while the connective tissues of the middle layer were disrupted. The granulation was prominent on the epithelial layer and was less prominent on the inner layer. As connective tissues were the main composites of the round-window membrane to maintain its configuration, they played important roles in the healing process of the perforation.

\section{はじめに}

最近, 内耳空破裂症の臨床例が多く報告されるようになり，その診断や治療法とも関連して本症 の病態に関心が向けられるようになってきた。しかし本症についての基礎的研究は少なく，はたし て内耳空破裂は自然閉鎖するのか, 閉鎖するとすればその治癒過程はいかなるあのであるかについ て充分に研究されていない. そてで内耳空破裂症の研究の一環として，モルモットの正円空に人工 的に穿孔をつくり, その修復過程を観察した. すなわち走査電顕により穿孔修復部の表面構造を, 光学顕微鏡によりその断面構造を観察し, 若干の知見を得たので報告する.

\section{実 験 方 法}

1. 走査電顕的観察

実験動物には白色成熟モルモット（体重 400 $\sim 750 \mathrm{~g}$ ) を用いた. イソゾール® (thyamylal sodium, 25〜35mg/kg i.p.) で麻酔後, 動物の頭 部を固定した。 さらにキシロカイン 所浸潤麻酔を加え，手術顕微鏡下に耳後部より 
中耳骨胞を開放し、ツチ・キヌタ骨を除去して 正円空を明視下においた，正円空膜の穿孔は先 端を尖らせた $0.3 \mathrm{~mm}$ 径のタングステン線をマニ ピュレーターを用いて正円空膜に刺入すること によって作製した。これらの処置は可能な限り 無菌的に抗てない，A B-P C 腹腔内に注射 することにより感染を予防した，術後はそのま ま動物を飼育ゲージにもどし，一定の日時を経 た後に創を再開放した。手術顕微鏡にて穿孔部 を観察した後，蝸牛ごと正円空を採取した，直 ちに $3 \%$ グルタールアルデヒドによる前固定, 1\%オスミウム酸による後固定をおこない，走 査型電子顕微鏡（日立 S500A）で正円空の観 察をおこなった。

\section{2 . 光学顕微鏡による観察}

実験手技の大略は走查電顕の場合之同じであ るが，アプローチならびに穿孔作製法を若干変 更した。すすなわち鼓膜・耳小骨などの伝音系を 可能な限り保存するために外耳道後壁と顔面神 経管の間の骨を削開して正円空にアプローチし た（図 1）。このアプローチにより生理学的実 験が可能となり，また中耳骨胞内での術後の肉 芽の増殖を減らすことができた，穿孔の作製に は25〜27ゲージの注射針を用いたが，乙れによ り正円空の線維走行を考慮して穿孔をつくるこ とができた，すなわち正円空の主線維の走行は 棈円形をしている正円空の短軸の方向なので, こてでは穿孔縁が主線維の走行と直交するよう に穿孔をおこした（図2）。

穿孔作製後，一定の日時を経過したのち創を 再開放し手術顕微鏡にて穿孔部を観察した。さ らにイソゾール深麻酔下で生理食塩水之 Heidenhain-Susa 固定液で生体還流をおこない蝸

結

表 1 に手術顕微鏡にて観察した穿孔修復の経 過を示す，早い例では 3 日目に遅くとも10日目 ごろには閉銷していた，表の中耳炎例は中耳骨 胞内に膿が充満し内耳炎を合併していたが，多 くは正円空が肉芽でおおわれ穿孔は一応閉銷し

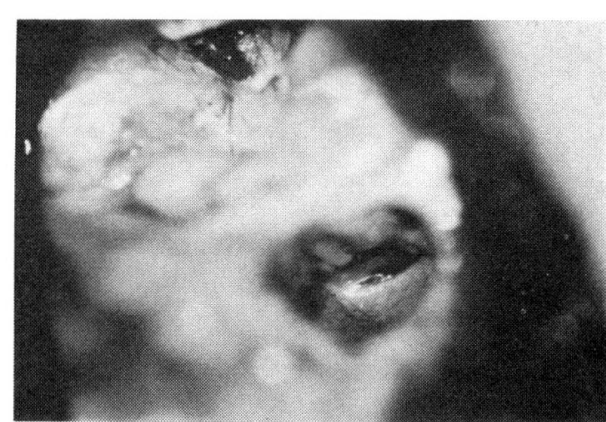

図 I 正円空の穿孔は外耳道後壁と顔面神経管の間を 削開し注射針を刺入しておてした。

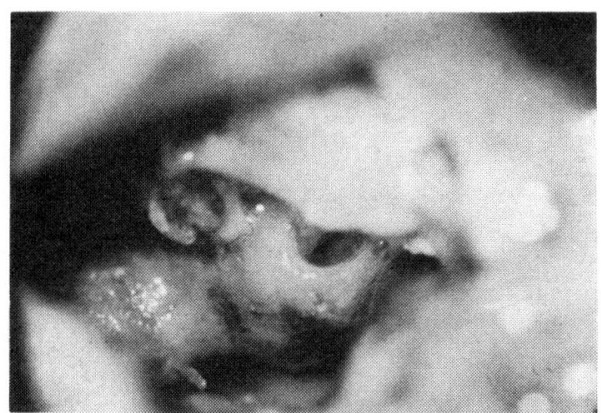

图 2 穿孔の状態を示す. 正円空を観察するために鼓 膜, ツチ・キヌタ骨等は除去してある.

牛を採取し，同固定液で一昼夜浸漬した後， 5 $\%$ 三塩化酢酸で脱灰，パラフィン包埋をおこな った．連続切片は破裂縁と直交する方向，すな わち主線維と平行な方向に切り出した。染色に は弾力線維の染色法であるアルデヒド・フクシ ン法を用いた。この方法により弾力線維は紫色 に染まる. 弾力線維を染色したのはモルモット の固有層では膠原線維は極めて少なく弾力線維 が豊富だからで，この染色法により固有層の識 別が容易となり粘膜層 (外側層) や内層之区別 できる.

\section{果}

ていた。なお穿孔作製直後の前庭症状（偏倚あ るいは自発眼振）は全く生じない例もあった が, 生じた例においても $1 \sim 2$ 日後には回復し た。 
表 I 穿孔修復の経過. 手術顕微鏡下での観察結果による

\begin{tabular}{|c|c|c|c|c|c|c|c|c|c|c|c|c|c|c|}
\hline & \multicolumn{13}{|c|}{ 穿孔作製から観察までの期間（日） } & \multirow{2}{*}{ 計 } \\
\hline & 2 & 3 & 4 & 5 & 6 & 7 & 8 & 9 & 10 & 11 & 14 & 21 & 28 & \\
\hline 穿孔閉鎖例 & & 1 & 1 & 1 & & 3 & 2 & & 2 & 1 & 4 & 1 & 1 & 17 \\
\hline 非閉鎖例 & 3 & 1 & 2 & 1 & & 3 & 1 & & & & & & & 11 \\
\hline 中耳炎 & & & 1 & & 1 & 1 & & 1 & & 1 & & & & 5 \\
\hline 計 & 3 & 2 & 4 & 2 & 1 & 7 & 3 & 1 & 2 & 2 & 4 & 1 & 1 & 33 \\
\hline
\end{tabular}

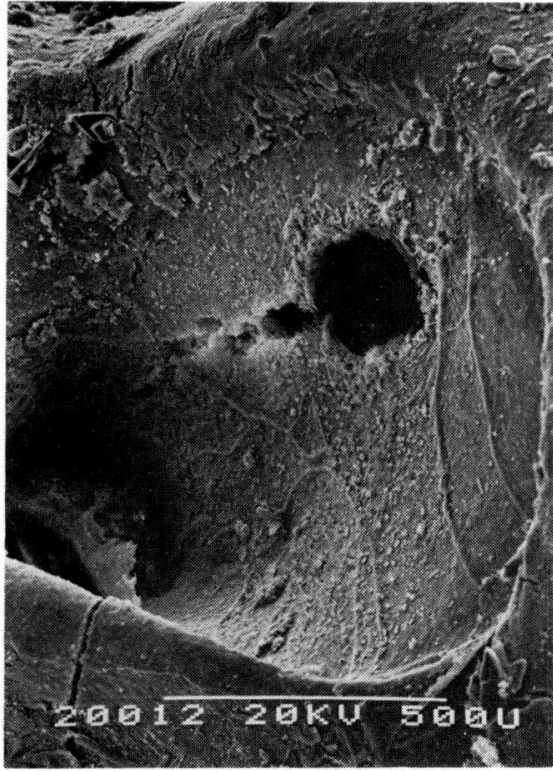

図 3 穿孔後 2 日目. 穿孔は閉鎖していない.

\section{1. 走査電顕的観察}

図 3 は穿孔作製後 2 日目例の所見である.断 端部に肉芽の増殖傾向がみられるが穿孔は大き く開いたままである。図4（a，b）は 4 日目 例であるが肉芽の形成が著明で穿孔はすでにみ られなかった，正円空左辺の大きな龟裂は組織 固定中に生じたアーチファクトである。図 5

（a，b）は 7 日目例であるがやはり肉芽性に 閉鎖されていた。

\section{考}

正円空膜は鼓室側の粘膜層，外リンパ液と接 する内層，その間にある固有層の 3 層からな り，その微細構造についてはすでに多くの報告
このように正门空の穿孔は肉芽にて閉鎖され るが，乙の肉芽は中耳側で増殖傾向が強く内耳 側ではあまりみられなかった。

2. 光学顕微鏡的観察

図6（a，b） は穿孔後10日目の正円空の断 面である. 弾力線維の断裂とそれを覆う粘膜層 側の肉芽の增殖がみられる，左側の線維は途中 から拡がるように疎となっているが，おそらく 穿孔を作った際に線維が折机込んでほぐれたた めと思われる。図 7 む10日目の例であるが，こ の例では正円空の辺縁部に穿孔が生じていた。 左中央付近で線維の部分的断裂がみられるが, おそらくこの部で内耳側に折れ込んだ断端が元 の位置にもどり肉芽性に閉鎖したものと推察さ れる. 図 8 は11日目の例で手術顕微鏡下で閉鎖 していると思われたが，断面所見では閉鎖は完 全ではない．弾力線維の断端は巻き込んだよう になっている，肉芽の増生は著明でない。

このように穿孔により線維が断裂したり，ほ ぐれたりしても断端部は元の位置にもどる傾向 を示していた．これは穿孔を中耳側から内耳側 に向けておこしたため, 内耳の液圧と正円空膜 の剛性によって穿孔の断端縁は元の位置にもど りやすかったためと思われる，一般の創傷治癒 におけると同殔，創面の密着が治癒過程におい て重要であるのは当然である.

\section{按}

がなされている(12)3． 服部ら4゙とると粘膜層 は鼓室粘膜の延長で 1 ～層の扁平あるいは低 立方状の細胞からなり，その直下に基底膜があ 

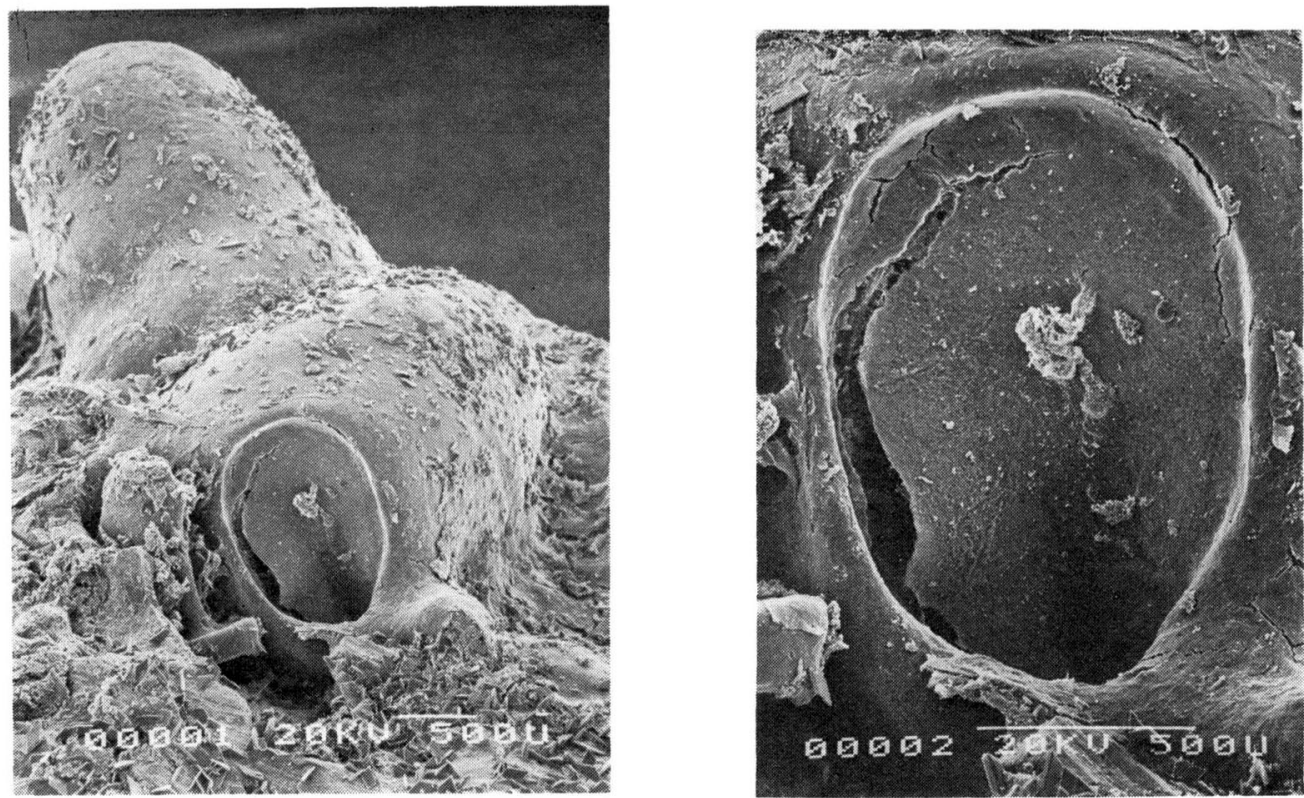

図 4 a . 穿孔後 4 日目. 穿孔は肉芽性に閉鎖していた．左縁の亀裂は固定中に生じたアーチファクト である。 b. その拡大図.
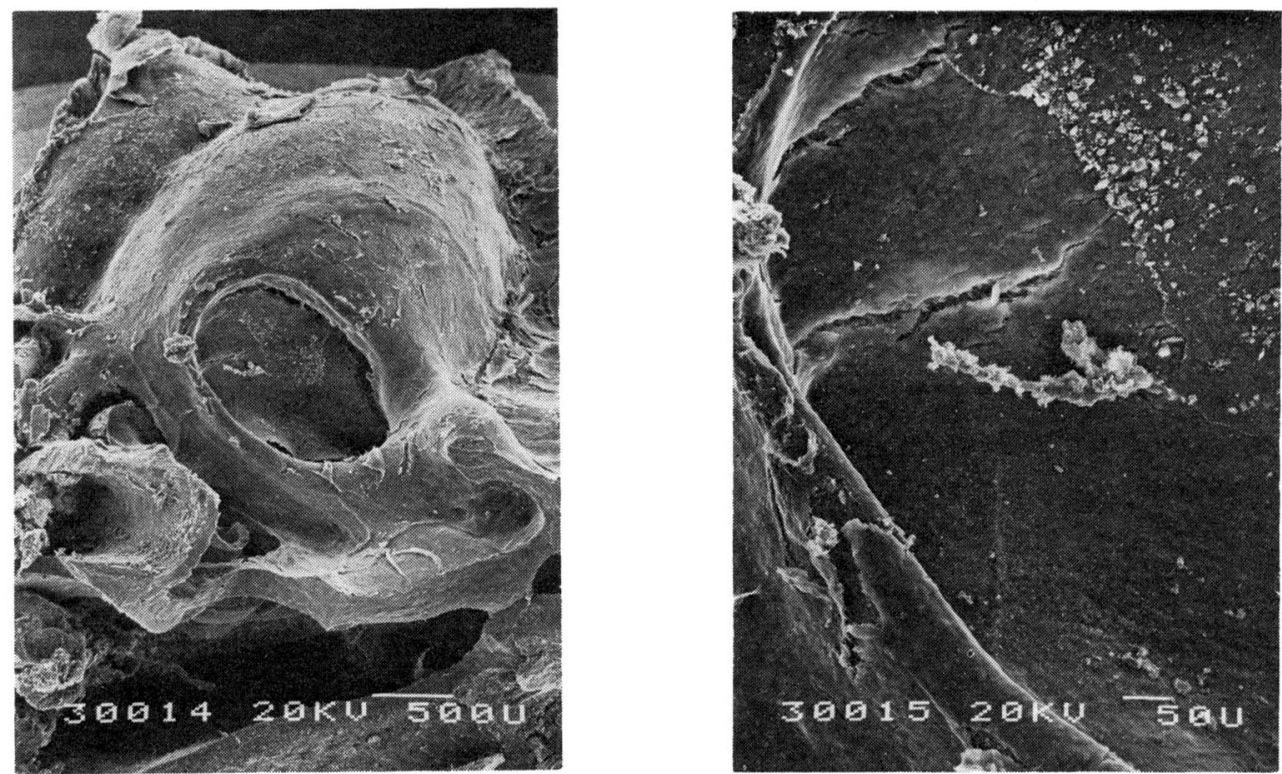

図 5.a．穿孔後 7 日目．穿孔は肉来性に閉鎖していた，辺縁部の亀裂はアーチファクトである. b. その拡大図 

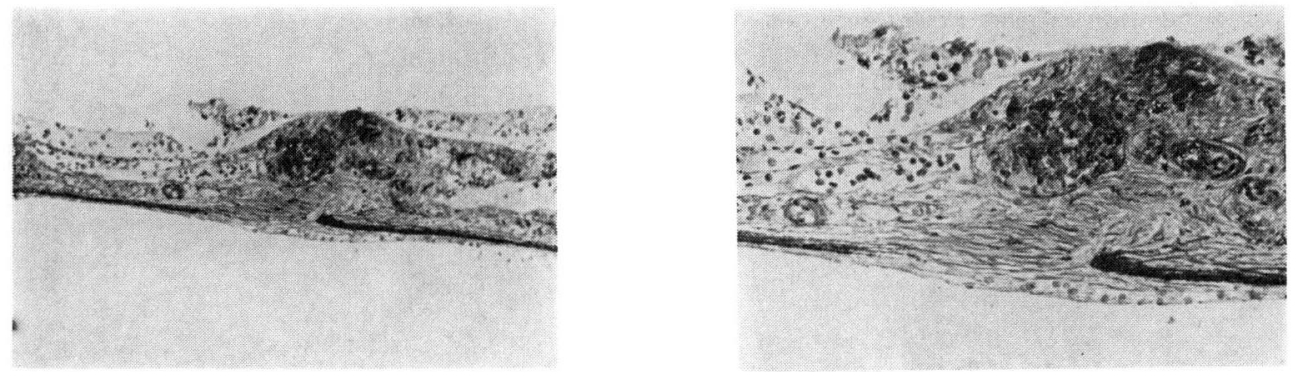

図 6. a. 穿孔後10日目. 上方が中耳側. 穿孔部には弾力線維の断裂がみられる. また粘膜層側には著

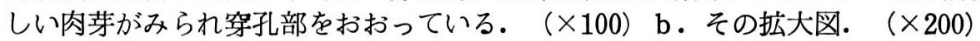

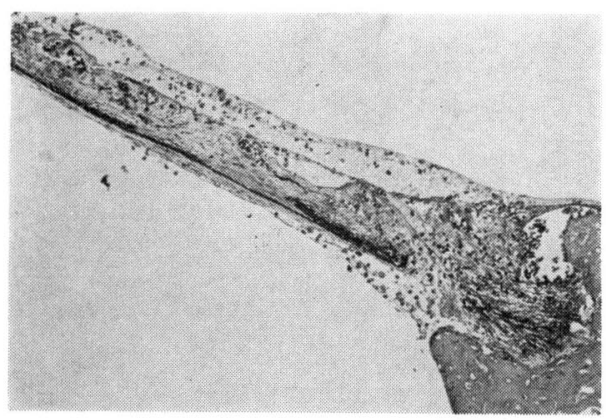

图 7 穿孔後 10 日目. 上方が中耳側. 正円空辺縁部に 穿孔を生じた例. 写真の中央部に弾力線維の部 分的断裂がみられる. $(\times 100)$

り固有層に移行する．内層は鼓室階を被覆する 細胞の連続で $1 \sim 2$ 層の扁平な細胞よりなり， 基底膜は認められず固有層との境界は明瞭でな い. 固有層は主として線維性結合組織よりなる 厚い層で，線維芽細胞，血管，神経などむ含ん でいるという。この線維性結合組織は比較的規 則正しく配列・走行しているといわれ， Link 5)は 1 ) Längsfaser 2 ) Anulus fibrosus externus 3 ) Anulus fibrosus internus $\odot 3$ 種 類に分類している．とのうち Längsfaser は主 線維とも呼ばれ ${ }^{6)}$, 線維性結合組織の大部分を 占め，楕円形を呈する正円空膜の短軸と平行に 走行する。との主線維はヒトでは太い膠原線維 と弾力線維からなる。しかし，モルモットでは 線維性結合組織の配列・走行はヒトと類似して いるむのの膠原線維の量はヒトに較べて極めて 少なく弾性線維が豊富であるといゔ.

このように正円空は中間層として結合織を持

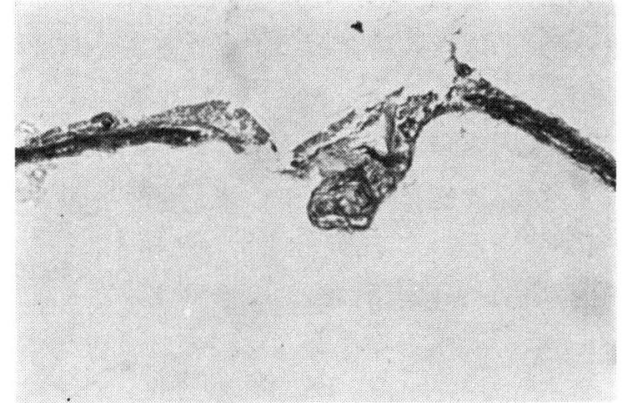

図 8 穿孔後11日目. 上方が中耳側. 穿孔の閉鎖は不 完全であり，破裂断端部の弾力線維は巻き込ん でいる. $(\times 200)$

つ以外は $4 \sim 5$ 層の細胞からなり, 中央で10 $\mu \mathrm{m}$ ，辺縁部で $70 \mu \mathrm{m}$ 之非常に薄( ${ }^{7)}$. 従って従 来加ら中耳炎症や局所使用薬剂の内耳への侵 入経路としても注目されていだ)。さらに最近 は内耳空破裂症の存在が広く知られるようにな り, 臨床面からも強く関心が持たれている.

ところで正円空膜破裂の機転としては内耳側 から力が作用する場合と中耳側から力が作用す る場合とが考えられる．正円空を間にはさんで 内耳と中耳に圧差が生じ，それが一定限度をて えれば破裂するのであるが，どれだけの圧差で 破裂が生じるかという実験は少ない. Harker ら は)はネコの脳脊䯣圧を上げることによって正 円㥶に破裂をおこしている。それによると最低 $120 \mathrm{mmHg}$ で破裂を生じる例もあったが非常 に個体差が大きかったという。

正円空の破裂と聴力との関係についてはすで に Simmons ら9), Axelsson ら ${ }^{10)}$ の報告があ 
る. Simmons らは CM を聴力回復の指標之 してネコで実験をおこない, 破裂によって生じ た聴覚障害は数日中に急激に回復し， $1 \sim 4$ 週 間目にはほぼ正常（6 dB 以内）にまで回復す るという，さらに，正円空に穿孔をつくるてと によって前庭症状が生じたとしても手術の翌日 には回復していることから, 外リンパ液の流出 は 1 日で停止するのではないかと推察してい る.一方, Axelsson らはモルモットを用いて 実験をおてなっているが，聴覚障害は全く生じ ないものから $40 \mathrm{~dB}$ の障害をおてすものまで 個体差があったが聴覚障害と解剖学的変化とは 必ずしも一致しなかったという。しかし13匹中 12匹に正円空穿孔の自然治癒がみられたのだか ら，少なくともモルモットの正円空は自然治癒 傾向が強いといえる.

今回の我々の実験の目的の 1 つは, 穿孔を生 じた正円空膜はどの程度の期間で自然治癒する か，また穿孔部にどのような組織学的変化が生 じるかを検討するととにあった。その結果，早 い例では 3 日目に遅くとも 10 日目ごろには閉鎖 し,やはりモルモットでは自然治癒傾向が強い
ことがうかがわれた。しかしヒトにおいては正 円空の構造が幾分異なることからこの動物実験 の結果をそのままヒトに適応することはできな いが, 多くの正円空破裂の臨床例で安静が保た れていれば自然治癒がみられているのでやはり ヒトに拈いても自然治癒傾向は強いものと推察 される。

また穿孔部の S EM，及び弾力線維染色によ る観察から，穿孔部の閉鎖は肉芽によってなさ れ，それは中耳側において著明であることが知 られた。従って肉芽の発生を抑制するステロイ ドなどは穿孔の閉鎖を遅延させる可能性があ り, 臨床上その使用には注意が必要であると考 えられる。

本実験の結果から，正円空に穿孔が生じても 比較的短期日の間に自然治癒しうることを示し た。しかし実際には穿孔の成因, 部位, 大きさ などにより治癒期間は異なるはずであり，乙れ らを考慮した検討が必要である．さらに穿孔に よる内耳の機能障害や解剖学的変化についても 不明の点が多く今後の課題と考えている.

\section{ま と め}

モルモットの正円空膜に実験的に穿孔をつくり，その治緰過程を走査電顕と光学顕微鏡にて観察 した. その結果穿孔は早いものでは 3 日目に遅くとも 10 日目でろまでには閉鎖することが分った. 走査電顕による観察から治癒した穿孔部は肉芽でおおわれているのが確認された。これは光顕標本 においても確かめられた。 また光顕標本を弾力線維染色するととによりモルモットの固有層の結合 織線維の染色ができ, 穿孔部の断面構造の観察が容易になることを示した.

本論文の要旨は第26回および第27回内耳生化学研究会において発表した.

文

1) Kawabata, I. and Paparella, M.M. : Fine structure of the round window membrane, Ann. Otol. Rhinol. Laryngol. $80: 13 \sim 26$, 1971.

2) 川端五十鈴, 石井英男 : 正円空膜の微細構造, 特 に固有層について一透過および走查電子顕微鏡に よる観察一. 日耳鼻 $75: 429 〜 435,1972$.

3 ）中井義明, 金子実: 正円空膜一微細構造ならびに

\section{献}

透過性について一. 耳鼻臨床 $68: 223 \sim 232$, 1975.

4 ）服部康夫，弓削庫太：鼓膜ならびに正円空膜の電 顕的研究一加令による変化について一. 耳鼻 25 : 1115 1138, 1979.

5) Link, R. : Beitrag zur Histologie der Membran des runden Fensters. Ztsch. Hals-Nasen-Ohrenarzt, Teil 1. $32: 295 \sim 307,1941 \sim$ 
1942.

6 ) Harty, M. : The secondary tympanic membrane and annular ligament. Ztsch. Mikr. Anat. Forsh. $70: 484 \sim 489,1963$.

7 ) Head, P.W. : Physiological considerations of pressure effects on the ear and sinuses in deep water diving. Diseases of the Ear, Nose and Throat, Basic Science. edited by J. Balantyne and J. Groves. Fourth Edition. 245 262, Butterworths Co., England, 1979.

8 ) Harker, L., Norante, J. and Rzu, J. : Experimental rupture of the round window membrane. Trans Am. Acad. Ophthalmol. Otolar- yngol. $78: 448 \sim 452,1974$.

9) Simmons, F. B., Burton, R. D. and Beatty, D. : Round window injury: auditory, behavioral and electrophysiological consequences in the cat. Trans Am. Acad. Ophthalmol. Otolaryngol. $66: 715 \sim 722,1962$.

10) Axelsson, A. et al. : Experimentally induced round window membrane lesions. Acta Otolaryngol. (Stockh) $84: 1 \sim 11,1977$.

原稿到着：昭和55年 4 月 24 日 別刷請求先：暁 清文 巨寀791-02愛媛県温泉郡重信町大字志津川 愛媛大学医学部耳鼻咽唉科学教室 